\title{
Analysis of Small Scale Topography and Local Precipitation in Bangka Belitung Island
}

\author{
Ratih Prasetya*1 dan Rizki Adzani \\ ${ }^{1}$ Education and Training Centre, The Agency for Meteorology Climatology and Geophysics \\ Jl. Angkasa I No. 2, Jakarta, 10720 \\ ${ }^{2}$ Meteorological Station of Pangkal Pinang, The Agency for Meteorology Climatology and Geophysics \\ Jl. Bandar Udara Depati Amir, Kepulauan Bangka Belitung, 33684
}

\begin{abstract}
Weather early warning forecast has been developed using various methods and data to investigate small scale weather characteristics. Each region, especially in low latitude has unique and dynamic local weather circulation. Bangka Belitung Island has a typical topography consists of a hilly region and directly adjacent to the sea. Thus, this expected to have a high impact on local weather circulation. The use of in-situ data (air temperature, rainfall amount also wind surface speed, and direction), weather satellite observation, and meteorological model is chosen to investigate the local weather circulation characteristic. Findings in this study are that topography has to influence and controlling local circulation such as the presence of land breeze and sea breeze supporting the formation of convective clouds around the hills in Bangka Belitung Island. The changes in air temperature between 7-10 LT affects the occurrence of rain in the afternoon, with a small correlation value so that it can be concluded there was no significant relationship. Wind surface analysis shows that strong sea breeze activity occurred during the MAM period. Himawari satellite imagery analysis showed that rain occurred in the afternoon and only occurred in the mainland region of Bangka Belitung.
\end{abstract}

Keywords: GSMAP; local circulation; temperature; transition period; wind speed and direction.

*Corresponding author: prasetyaratih2@gmail.com

http://dx.doi.org/10.12962/j24604682.v16i2.6301

2460-4682 (c)Departemen Fisika FSains-ITS

\section{INTRODUCTION}

Weather early warning procedure has been developed in Indonesia in line with international regulation stated that $\mathrm{Na}-$ tional Meteorological and Hydrologicals role would involve in risk reduction element that provision of hazard forecasts and early warnings to support emergency preparedness and response; climate data and forecasts (probabilistic information on hazards and their changing patterns) to support medium and long-term sectoral [1]. As the authorized institution, the Agency for Meteorology Climatology and Geophysics (BMKG) has a Standard Operating Procedure to be implemented by each forecaster in Indonesia. Regarding with that matter, the updated knowledge and comprehension of each region local weather needs to be updated by forecaster to produce more accurate weather early warning forecast since Indonesia as a maritime continent has a very unique and typical topographical condition that a thousand islands with complex topography have strongly influenced the character of convection in the atmosphere. The islands induce strong diurnal cycles in precipitation, as well as spatial structures in time-mean rainfall that closely follow mountains and coastlines [2]. Observation analysis in the Caribbean island of Dominica has shown that low-level wind controls observed shallow convection over that Caribbean Island, with a transition from thermal to mechanical forcing as wind speed increases [3].

Precipitation over small tropical islands may induce pre- vailing wind speed strongly controls rain over the island [4]. The result of extreme rainfall analysis in Bangka shown that North Bangka island has a high frequency if extreme rainfall [5]. Thus, in this study, we are interested to investigate the local precipitation over an island in Indonesia maritime continent which is Bangka Belitung Islands that was hit by flood both in Bangka and Belitung island.

Bangka Belitung Islands (abbreviated as Babel) is a province in Indonesia consisting of two main islands namely Bangka Island and Belitung Island as well as hundreds of smaller islands, with a total of 470 occupied islands and only 50 islands inhabited. Bangka Belitung is located in the eastern part of the island of Sumatra, close to the South Sumatra Province.

Bangka Belitung topography included the straits, The Bangka Strait separates Sumatra Island and Bangka Island, while the Gaspar Strait separates Bangka Island and Belitung Island. In the northern part of the province is the South China Sea, the southern part is the Java Sea and Kalimantan Island on the east side of the province, separated from Belitung Island by Karimata Strait.

Topographically, Bangka Belitung Island is lowland and hilly region with various shapes of the island, it also has a coast shape with straits that highly relates with small scale weather condition that likely leads to the sea breeze and land breeze, the mountain breeze, and turbulence. Thus, the topographical factor plays a vital role in this region. 
The limited number of weather surface stations in Bangka Island causing extreme weather events difficult to be predicted and analyzed. Thus, the utilization of remote sensing products from weather radar observation is one of the solutions. A radar network in Indonesia containing 41 unit radars can greatly assist the analysis and prediction of convective clouds formation which could lead to extreme weather events. A weather radar is able to detect near real-time weather conditions and has high spatial resolution with radius coverage up to $240 \mathrm{~km}$.

The representation of fine-scale small weather phenomena is generated by high-resolution surface conditions, notably orographic, coastlines, and surface types [6]. The inclusion of elevation as a covariate lowered the errors, particularly for interpolation of temperature, wind speed, and solar radiation [7]. There is a beneficial effect of orography on the predictability of convection in the absence of strong dynamical forcing especially for short lead times, also a positive impact of orography on the predictability of deep convection [8].

The weather system of cloud formation and weather patterns often vary as a result of topographical condition influences such as sea and land breeze, the mountain breeze, and also turbulence, in meteorology it is known as small scale weather system.

The windward sides of high mountain ranges are a function of location, and correct determination of the spatial distribution of meteorological variables is as important as their measurements [7].

Identification of relationships between the maximum precipitation and selected topographic and geographic attributes [9]

The subject of orographic rain pattern has studied [10], on the windward side, forced lifting on approaching air masses causes the release of rainfall and an increase in precipitation with elevation. Airflow indices computed from sea-level pressure have been used also to study the temporal and spatial distribution of precipitation [11]; [12]. In general, a good correlation is found between precipitation and airflow indices.

Classification of orographic precipitation by several mechanisms review with complex interplaythose are the dynamic response of convective systems such as diurnal heating, the stability of the upward current, and wind shear; the shape of terrain causing blocking or unblocking of the current; microphysical processes with the topography; and so on [13]. Considering the weak predictability of the thunderstorms at the convective scale combined with the small sizes of the watersheds (between 200 and $2000 \mathrm{~km} 2$ ) that are affected by flash floods, probabilistic approaches based on highresolution forecasts have certainly to be considered in the future to cope with these uncertainties [14].

Thus, a comprehensive study of local circulation in Bangka Belitung is investigated to help forecaster improving the accuracy of the short-term weather forecast, especially the weather early warning forecast by investigating weather-related factors.

\section{METHOD}

This study using analysis of descriptive quantitative method through data processing and analysis of meteorological factors categorized in 4 stages. The stages are referring to a sequence in weather forecast analysis of weather parameters analysis on a local scale.

This study conducted an analysis of the topographical condition of the region to understand the effect of forming a common typical local weather circulation as the first stage. The effects in the first stage will influence characteristics of surface weather parameters, thus the second stage we need to conduct the Diurnal pattern of these weather parameters such as Temperature, Mean Sea Level Pressure (MSLP), and Wind Surface Speed and Direction Variations in the second stage. This analysis results in weather parameters diurnal pattern will contribute to low-level cloud formation, so we need to do the third stage analysis of interpretation weather radar and weather satellite products to relate topographical factors and local circulation with the diurnal pattern of convective cloud development. The fourth stage will be conducted by interpretation of GSMap product near a real-time per hour to comprehend the rainfall pattern that forms when the dominant local factor occurs.

Data used in this study are:

- In-situ data collected from Meteorological Station of Depati Amir, Pangkal Pinang, Bangka of 10 years monthly rainfall data, 5 years hourly air temperature data, and 5 years of hourly wind surface data.

- Meteorological Satellite Data collected from Himawari Satellite utilizing GMSLPD Visualization Software dated 7 Mei 2017 in a transition season

- Meteorological models data analysis utilizing the GSMap data to visualize the distribution of Total Precipitation dated 16 July 2017 in a transition season

\section{RESULTS AND DISCUSSIONS}

\section{First stage}

Bangka Belitung is divided into two main islands namely Bangka Island and Belitung Island. Topographic conditions of this mostly lowlands, valleys, and a small part of the mountains and hills. Low altitude average of about 50 meters above sea level. The height of the mountainous areas, among others, for Mount Maras on the northern part of Bangka Island reaches 700 meters, the Mountain of Sharp Legs in Belitung has an altitude of approximately 500 meters (Fig.1).

Whereas for hilly areas such as Menumbing Hill the height reaches approximately 445 meters and Bukit Mangkoldi Central Bangka with a height of about 400 meters. The location of the Bangka Belitung Islands in the north is bordered by the South China Sea, in the east, it is bordered by the Karimata Strait, in the south it is bordered by the Java Sea and in the west, it is bordered by the Bangka Strait. 


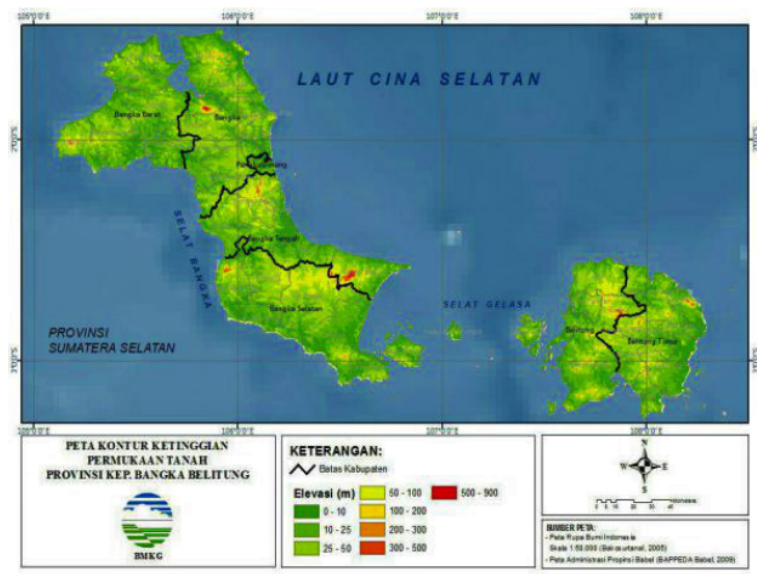

FIG. 1: Bangka Belitung topographical map (Source: BMKG, Bakosurtanal \& BAPPEDA Babel 2009)

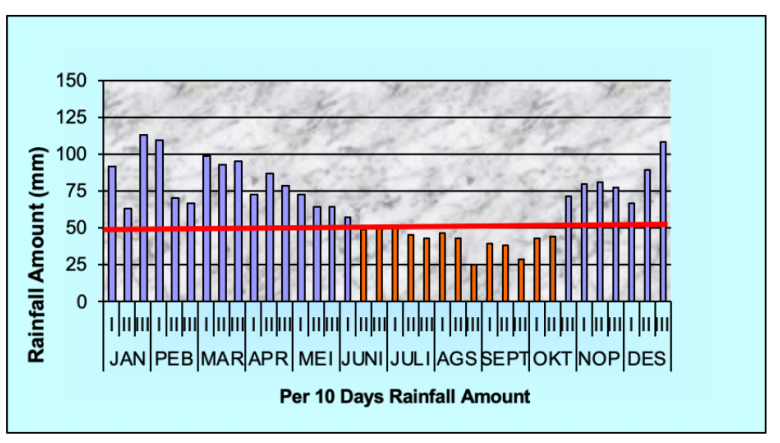

FIG. 2: Pangkalpinang Average Rainfall in 2007-2016.

In general, climatic conditions in Kep. Bangka Belitung is influenced by monsoonal winds. When the Western monsoon is active, in Kep. Bangka Belitung is the rainy season and when the monsoon is active, the dry season occurs in Kep. Bangka Belitung.

\section{Second stage}

Fig. 2 shows that Pangkal Pinang is categorized as type of monsoonal rainfall pattern, namely the rain pattern where the area can be clearly distinguished between the rainy season and the dry season. Thus, to see the onset of each season with more precision can be seen from the graph of accumulation of rainfall in the dasarian. The rainy season period is in the dasarian period of III, October to the dasarian in June. Whereas the dry season is in the second dasarian period from June to the second dasarian in October. The Transition Period is in the dasarian III period of May to the dasarian I of June and between the dasarian I of October to the dasarian II of October. The length of the Rainy season in the Pangkalpinang region is 23 Dasari or approximately 7 months, while the length of the Dry Season is 13 Dasarian.

The rainfall pattern (Fig. 3) shows an imperfect monsoonal rainfall pattern because in that pattern there are two peaks of the rainy season. This can be seen from the graphic patterns that are shaped like the letter $U$ so that the rainy season

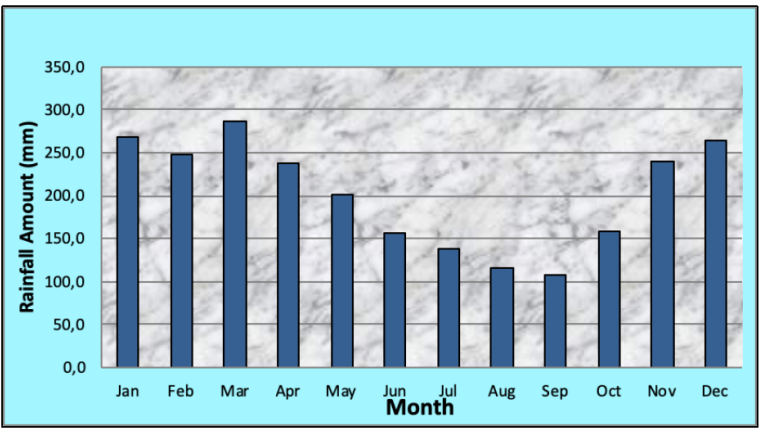

FIG. 3: Pangkalpinang Average Monthly Rainfall in 2007-2016.

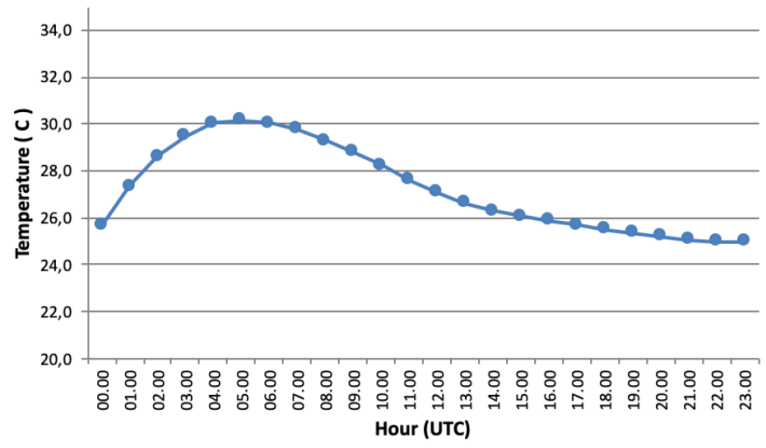

FIG. 4: Daily Average Air Temperature Graph Pangkal pinang Meteorological Station Period of 2012-2016.

in Pangkal pinang is obtained in January, February, March, April, May, October, November, and December. While the dry season occurs 4 months, namely in June, July, August, and September.

The inclusion of elevation as a covariate lowered the errors, particularly for interpolation of temperature, wind speed, and solar radiation [7]. Thus, this study investigates about the aforementioned weather parameters of temperature and wind speed, the results as given below.

Fig 4. illustrates the diurnal pattern of average air temperatures over the past 5 years in the Pangkal pinang region. Av-

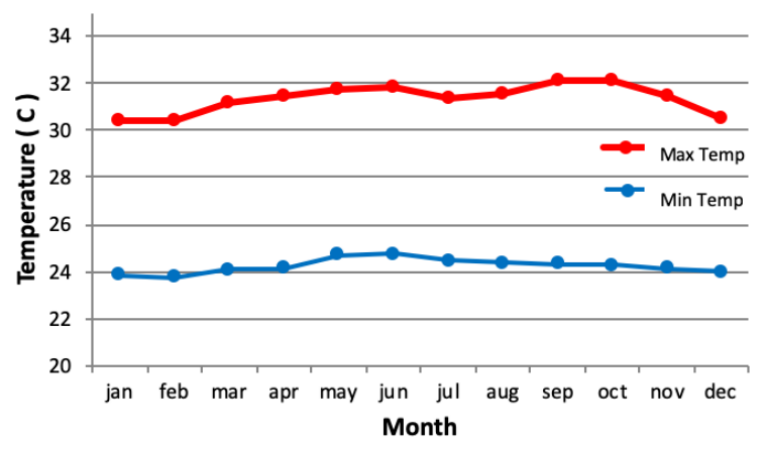

FIG. 5: Minimum and Maximum Temperature Charts 2012-2016 period. 


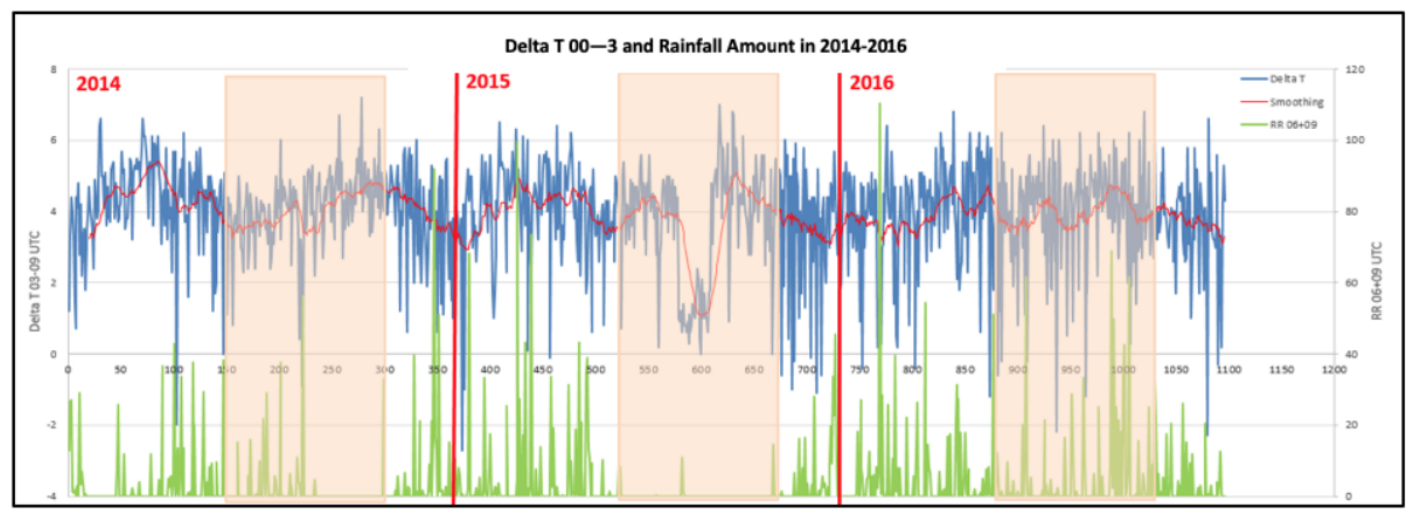

FIG. 6: Delta T at 0003 UTC and Rainfall amount in 20142016.

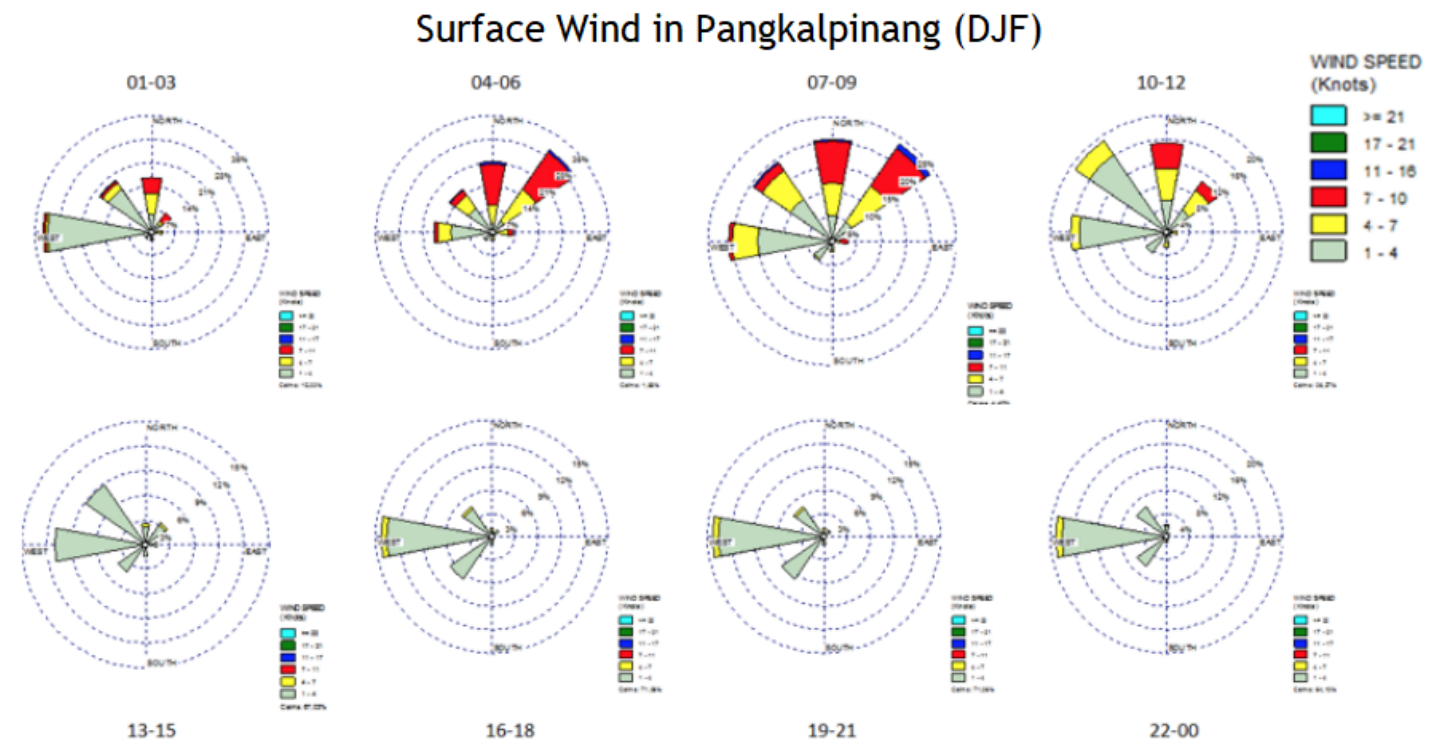

FIG. 7: Windrose in Pangkal Pinang in Desember, Januari and Februari (DJF).

erage daily temperatures range from 24 - 31 C. Evolution of daily scale temperature has 1 peak / highest average daily temperature at 05.00 - 06.00 UTC or $12.00-13.00 \mathrm{WIB}$, and 1 valley / lowest average temperature value in the period 22.00 23.00 UTC or around 05.00 - $06.00 \mathrm{WIB}$. The rate of increase in air temperature looks more intense in the period 00.00 UTC to $06.00 \mathrm{UTC}$, i.e. when the insulation is active. While the rate of decrease in air temperature occurs at 08:00 to 16:00 UTC.

Monthly variations of the minimum and maximum temperatures (Fig.5) of Pangkal pinang Meteorological Station for the past 5 years can be seen in the graph above. It appears that the variation of these two temperatures from month to month is not very striking. The maximum temperature pattern has two peaks / maximum values and one valley / minimum value. Whereas the minimum temperature pattern has one peak / maximum value and one valley / minimum value. The highest maximum temperatures occur in September and October. The lowest minimum temperature occurs in February.
Fig 6. shows the temperature difference pattern at 00 and 03 UTC which is connected with the occurrence of rain in the afternoon in the Pangkal pinang area. The blue line is the temperature difference value for three years and the average value can be seen on the red line. The green graph shows the rainfall that occurred in the afternoon. After calculating the correlation value between the two parameters, the data for three years resulted in a correlation value of -0.0232 , during the dry season the correlation value was 0.011 and during the rainy season, the correlation value was -0.043 .

This shows the correlation value between the two parameters is very small and insignificant, which can also be seen in the patterns of the two different graphs. The temperature delta value of $00-03 \geq 3^{\circ} \mathrm{C}$ has a strong potential to cause rain in the afternoon/evening seems inconsistently proven. For example, there are many instances where the delta temperature is $00-03 \geq 3^{\circ} \mathrm{C}$ but there is no rain or very small amounts of rain occur. So, it can be concluded that this temperature delta concept cannot yet be used as a reference in detecting the po- 


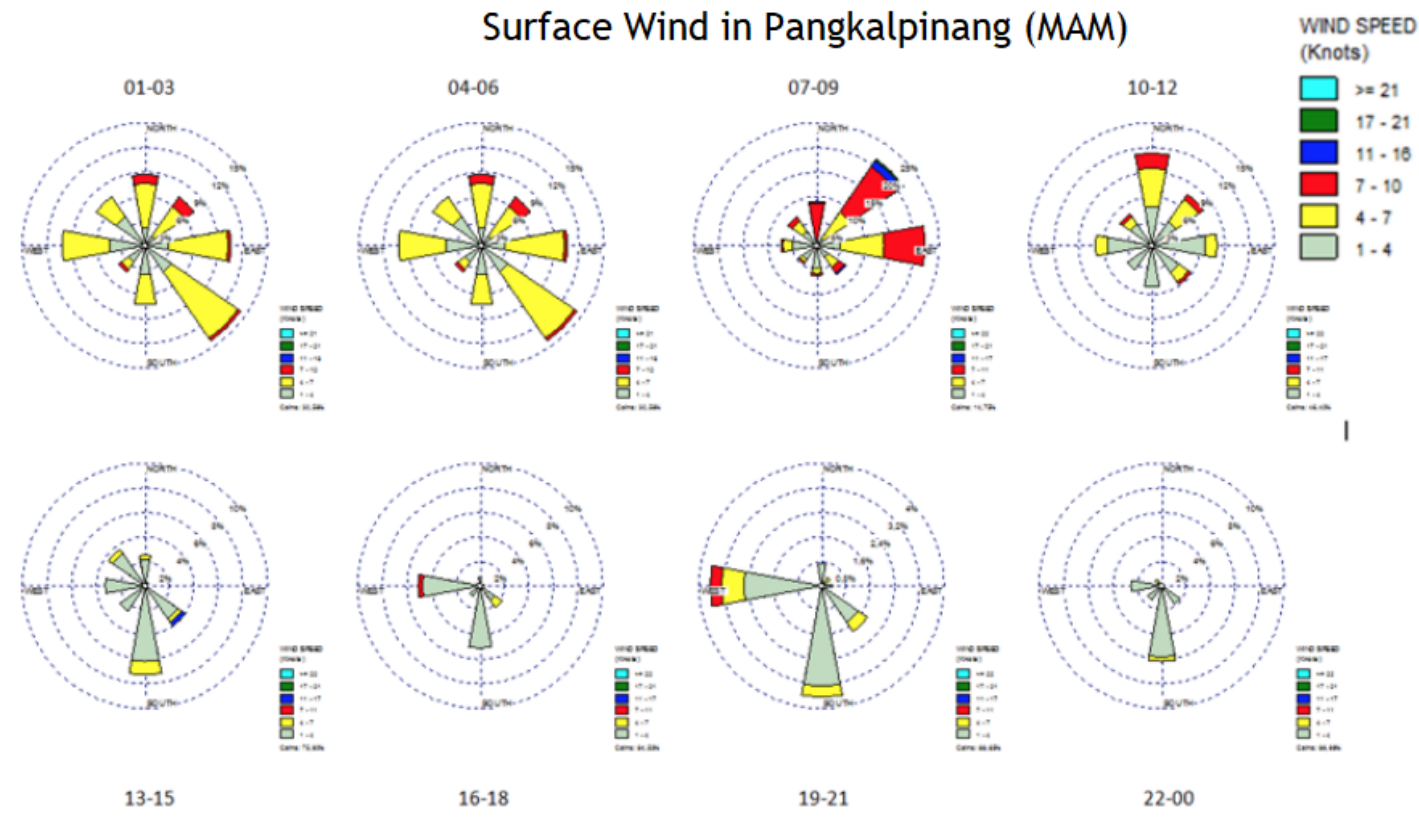

FIG. 8: Windrose in Pangkal Pinang in Maret, April and May (MAM).

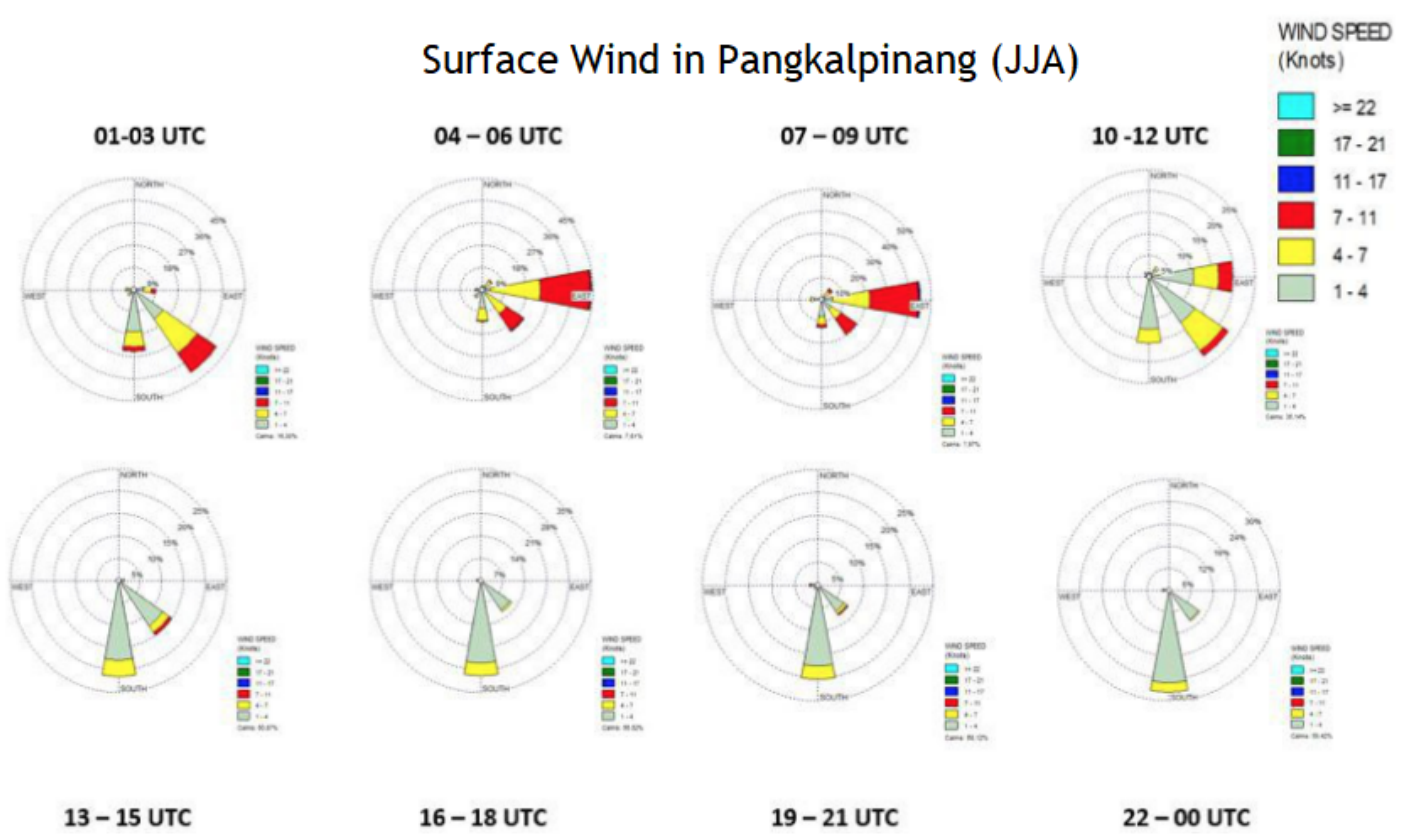

FIG. 9: Windrose in Pangkal Pinang in June, July and August (JJA).

tential for connectivity in the Pangkal pinang region.

Surface wind windrose (Fig. 7) at the Pangkalpinang Meteorological Station, in the December, January, and February (DJF) month showing that the dominant wind blows from the West - North direction. The windrose graph indicated the rainy season where the western monsoons are active. This condition resulted in the direction of the wind blowing is dominantly influenced by the synoptic-scale factor. So that local scale winds such as sea breezes are less influential in this pe- riod.

The MAM period in the Pangkal pinang region is a transition period from the rainy season to the dry season. Fig. 8 on the wind blows from all directions, but in the afternoon the dominant wind blows from the Northeast - Southeast. This condition shows that during the day the sea wind activity is quite strong, this wind comes from the waters of the Karimata strait located east of Pangkal pinang. The wind speed slowly weakens in the afternoon until the evening, and at cer- 


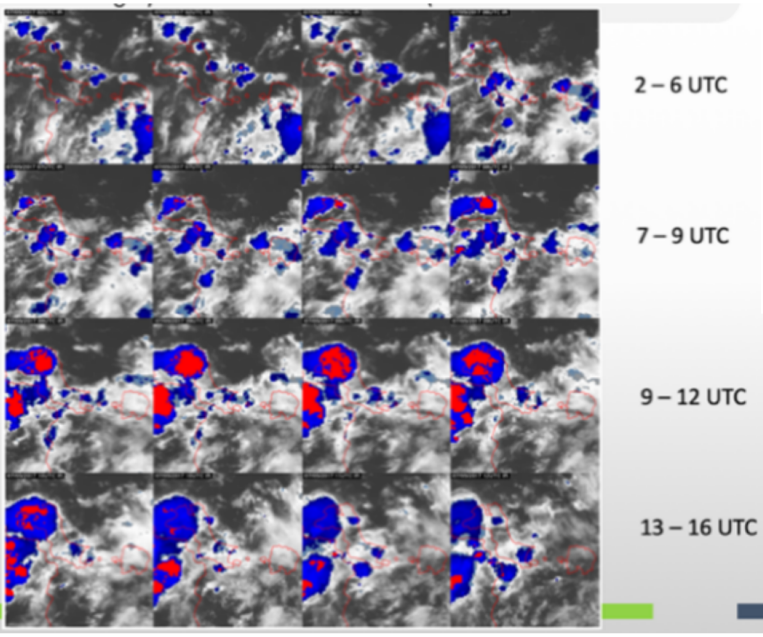

FIG. 10: IR Satellite Imagery 7 May 2017 at 02 to 12 UTC.

tain times the dominant wind direction blows from the West which indicates land wind active.

In the JJA period in (Fig. 9) the Pangkal pinang region, it has entered the dry season where the eastern monsoon is active. Based on the windrose image above, in the JJA period, the dominant wind blows from the East - South direction. During the day the wind blows from the east at a fairly strong speed, this condition indicates the presence of sea wind activity which is also strengthened by the influence of synoptic winds. So in this period, it is difficult to distinguish between sea winds and synoptic winds because the dominant wind direction that blows comes from the same direction.

\section{Third stage}

The satellite imagery in Fig.10 was taken on May 7, 2017, in the Bangka Belitung Islands region. In the Babylonian region, May is a transition period from the rainy season to the dry season. During the transition period, the growth of convective clouds is quite often formed in the afternoon until the afternoon with the character of formation that is not extensive but spread over several areas.

One of the other characteristics of cloud growth in the convective process is rapid cloud growth in the afternoon until the afternoon. Changes in cloud peak temperature in time series can be used as a method for observing the convective cloud growth process. As in the case above, at 2-6 UTC on Bangka Island, there are several small cumulus cloud cells which are shown in frames 1-4. Changes in the lower cloud peak temperature indicate the growing phase occurs from frames 5-8 which occurred during 120 minutes from 7-9 UTC with a fairly even location from the north, center, to the south of Bangka Island. The mature or mature phase of the Cumulonimbus cloud that occurs is seen in frame 9-12 which is indicated by the presence of two cloud cells that grow into Cumulonimbus namely in the northern part of Bangka Island and Palembang's east coast.

Frame 13-16 shows the decay phase activity which is marked by the beginning of the reduction in the area of the

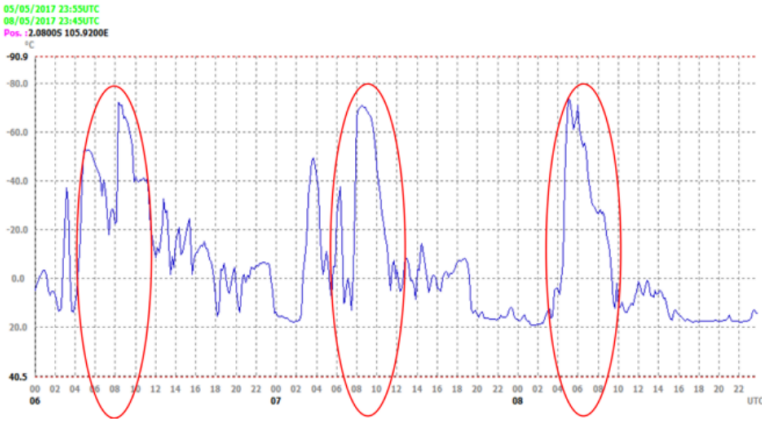

FIG. 11: Pangkal pinang Cloud Peak Temperature Chart 6 to 8 May 2017.

red cloud top temperature (the lowest temperature) and the expansion of the blue area which indicates that the parts of the Cumulonimbus cloud are falling into the rain and other clouds such as stratus, altostratus, and high clouds in the form of solid cirrus which is the remnant of the Cumulonimbus cloud base, this condition occurs for 120 minutes from 10-12 UTC.

The temporal pattern of the cloud top temperature (Fig.11) above is a picture of convective activity in Pangkalpinang from 6 to 8 May 2017. Bangka Island is an island with a strong potential for local disturbances, but we need to be careful in linking the graph above with the diurnal pattern of cloud growth. The condition of local scale disruption which is characterized by convective cloud growth usually starts before noon with the peak of growth between noon to evening. The patterns shown on 6 to 8 can be related to local-scale conditions that strengthen during the day. Convective cloud growth at 3 UTC or 10 WIB until 5 UTC or 12 WIB at which time solar radiation is at its maximum position, resulting in warming in the land area which increases the potential for sea wind circulation activity. The peak of convective cloud growth affiliated with the mature phase of the Cumulonimbus cloud occurs between noon to evening, ie 6 UTC or 13 WIB until 9 UTC or 16 WIB. Stronger convective activity during the day is associated with the strengthening of sea breezes especially those from the Karimata Strait east of Bangka Island which carry a lot of water vapor.

GSMap image (Fig.12) processing using the GRADS application was carried out on the Belitung Island flooding event on July 16,2017 . The total precipitation map produced showed a very significant pattern in the Bangka Belitung Islands region, especially in Belitung Island. The red color in the rainfall pattern that covers Belitung Island and Gelasa Strait gives an overview of the estimation of extreme rainfall that occurred on July 16, 2017, which is between 100 to $150 \mathrm{~mm}$.

The GSMap data that has been collected, in addition to being processed to produce a map of estimated total precipitation, is also processed into a map of the frequency of heavy rain. On the map, the frequency of heavy rainfall with intensities above 9 mm (Fig. 13) also covers the areas of Belitung Island and southern Bangka Island. Specifically, in Belitung Island, the frequency of heavy rainfall is dominated by the light brown color which shows frequencies between 4 to 6 times. The maximum rainfall frequency that is 6 to 8 times occurs 


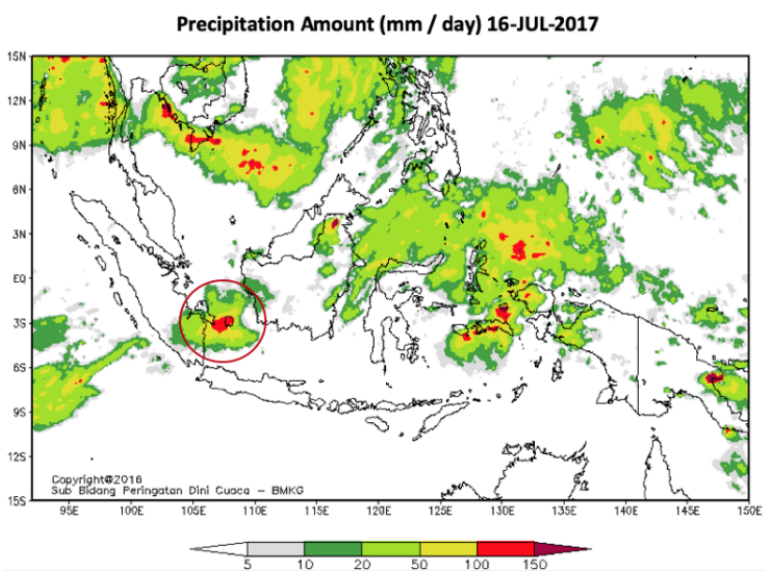

FIG. 12: Map of Total Precipitation GSMap on July 16, 2017.

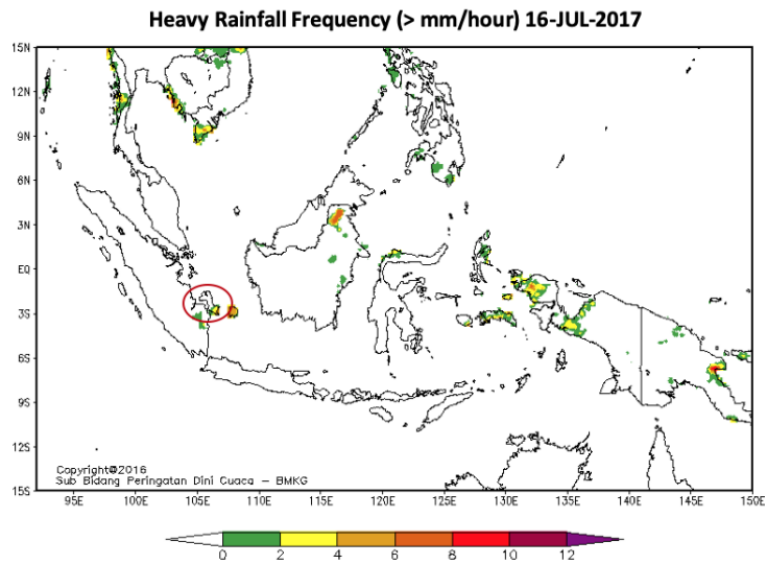

FIG. 13: Map of Frequency of GSMap Heavy Rain Events on July 16, 2017.

at the southwestern tip of Belitung Island which is marked in dark brown.

\section{CONCLUSION}

This study resulted that local weather system analysis in the Bangka Belitung Islands including topographical map analysis, identification of average dasarian rainfall, diurnal temper- ature patterns, diurnal scale surface winds, spatial map analysis of TRMM rainfall data and analysis of estimated rainfall distribution with GSMap data can be concluded that Bangka Belitung Island, which is surrounded by waters and hilly surface contours, has directly become the main factors in controlling local circulation such as the presence of land breeze and sea breeze activity affected the formation of convective clouds around the hills.

The changes in air temperature between 7-10 LT affects the occurrence of rain in the afternoon, with a small correlation value so that it can be concluded there was no significant relationship. A correlation value of -0.0232 , during the dry season the correlation value was 0.011 and during the rainy season, the correlation value was -0.043 . This shows the correlation value between the two parameters is very small and insignificant. Diurnal scale surface wind analysis using the windrose method shows that strong sea breeze activity occurred during the MAM period, at which time the Pangkal pinang and surrounding areas were in transition from the rainy season to the dry season.

Based on the analysis of satellite imagery, it showed that rain occurred in the afternoon and only occurred in the mainland region of Bangka Belitung. This means that there are local circulation occurs either due to orography, convection, or land and sea breeze.

Utilization of GSMap rainfall estimation data in weather analysis of extreme rain events in Belitung on July 16, 2017, shows that there is a heavy rainfall pattern on Belitung Island so that the use of this data can be used as one of the methods of analysis in extreme weather events.

\section{Acknowledgments}

This paper and the research behind it would not have been possible without the exceptional support of our supervisor, The Head of Education and Training, BMKG, and The Head of Pangkal Pinang Meteorological Station, BMKG. Their enthusiasm, knowledge and exacting attention to detail have been an inspiration also kept my work on track especially in this research document as an output from meteorological training in BMKG. Forecasters team in Pangkal Pinang meteorological station that willing to kindly help us in collecting all data needed in this research and also shared all valuable information about Bangka Island weather forecast experiences.
[1] GFCS, Climate Services for Supporting Climate Change Adaptation, no. 1170. 2016.

[2] M. Biasutti, A. H. Sobel, S. J. Camargo, and T. T. Creyts, Projected changes in the physical climate of the Gulf Coast and Caribbean, Clim. Change, vol. 112, no. 34, pp. 819845, 2012.

[3] A. D. Nugent, R. B. Smith, and J. R. Minder, Wind speed control of tropical orographic convection, J. Atmos. Sci., vol. 71, no. 7, pp. 26952712, 2014.

[4] S. Wang and A. H. Sobel, Factors controlling rain on small tropical Islands: Diurnal cycle, large-scale wind speed, and topog- raphy, J. Atmos. Sci., vol. 74, no. 11, pp. 35153532, 2017.

[5] A. Fadholi and R. Adzani, Analisis Frekuensi Curah HUjan Ekstrem Kepulauan Bangka Belitung Berbasis Data Climate Hazard Group Infra-Red Precipitation With Station (CHIRPS), Gea. J. Pendidik. Geogr., vol. 18, no. April, pp. 2232, 2018.

[6] Paper Iv Phoolji, 2006.

[7] H. Apaydin, A. S. Anli, and F. Ozturk, Evaluation of topographical and geographical effects on some climatic parameters in the Central Anatolia Region of Turkey, Int. J. Climatol., vol. 31, no. 9, pp. 12641279, 2011. 
[8] K. Bachmann, C. Keil, G. C. Craig, M. Weissmann, and C. A. Welzbacher, Predictability of deep convection in idealized and operational forecasts: Effects of radar data assimilation, orography, and synoptic weather regime, Mon. Weather Rev., vol. 148, no. 1, pp. 6381, 2020.

[9 ] C. E. KONRAD II, Relationships Between Precipitation Event Types and Topography in the Southern Blue Ridge Mountains of the Southeastern Usa, Int. J. Climatol., vol. 16, no. 1, pp. 4962, 1996.

[10] B. Johansson and D. Chen, The influence of wind and topography on precipitation distribution in Sweden: Statistical analysis and modelling, Int. J. Climatol., vol. 23, no. 12, pp. 15231535, 2003.

[11] D. Conway, M. Krol, J. Alcamo, and M. Hulme, Future avail- ability of water in Egypt: The interaction of global, regional, and basin scale driving forces in the Nile Basin, Ambio, vol. 25, no. 5, pp. 336342, 1996.

[12] M. L. Linderson, Objective classification of atmospheric circulation over Southern Scandinavia, Int. J. Climatol., vol. 21, no. 2, pp. 155169, 2001.

[13] R. A. H. Jr, Orographic Effects on Precipitating Clouds, Rev. Geophys., no. 2011, pp. 147, 2012.

[14] K. Chancibault, S. Anquetin, V. Ducrocq, and G. M. Saulnier, Hydrological evaluation of high-resolution precipitation forecasts of the Gard flash-flood events (8-9 September 2002), Q. J. R. Meteorol. Soc., vol. 132, no. 617, pp. 10911117, 2006. 